Orientalia Christiana Cracoviensia 4 (2012), s. 49-58

DOI: http://dx.doi.org/10.15633/ochc. 1030

Ihor Lylo

Lwowski Uniwersytet Narodowy im. Iwana Franki

\title{
Grecy we Lwowie: zapomniani obywatele
}

Lwów - miasto-warownia i ważne centrum życia ekonomicznego na pograniczu polsko-ukraińskim daje doskonałą okazję do badań nad historią małych grup etnicznych mieszkających na tym terenie od czasów wczesnego średniowiecza. Badacze polscy i ukraińscy zrobili w tym kierunku dużo ${ }^{1}$. Szczególnym zainteresowaniem cieszył się temat wschodnich wpływów pojawiających się we Lwowie wraz z kupcami i podróżnikami przybywającymi z Turcji, Persji, Carstwa Moskiewskiego czy państw naddunajskich. Centralną pozycję w tych badaniach zawsze zajmowała działalność wspólnoty ormiańskiej. Bez wątpienia kupcy ormiańscy stanowili potężną i wpływową grupę, która do pierwszej połowy XVII wieku w znacznym stopniu zapewniła sobie kontrolę nad lwowskim handlem, jeśli chodzi o wymianę ze Wschodem. Nadal popularne jest przysłowie: „Gdzie przychodzi jeden Grek, tam płacze pięciu Żydów. Jeżeli jednak przyjdzie Ormianin - płaczą i Grecy, i Żydzi”. Ormianie usunęli zatem w cień inne grupy napływające do miasta z krajów Orientu. W naszej rozprawie chcemy zwrócić szczególną uwagę na jedną z tych grup, a mianowicie na Greków.

Kronikarz Lwowa Jan Alnpek na początku XVII wieku informuje, że Rynek jest miejscem gdzie spotykamy „tłum kupców, którzy napływają do

${ }^{1}$ Я. Ісаєвич, Братства та їх роль в розвитку української культури XVI-XVII cm., Київ 1966; В. Кривонос, До питання про діяльність середземноморських греків у Львові в XVI - середині XVII cm., [w:] Lwów: miasto, społeczeństwo, kultura. Studia z dziejów Lwowa, t. 2, Kraków 1998, s. 59-67; I. Лильо, Нариси з історї̈ грецької громади міста Львова в 16-17 cm., Львів, 2002; W. Wagner, Handel dawnego Jarostawia do połowy XVII w., [w:] Prace historyczne ku uczczenia 50-lecia Akademickiego Koła Historyków Uniwersytetu J. Kazimierza we Lwowie, Lwów 1929; R. Szczygieł, Jarmarki jarosławskie i ich rola w handlu Rzeczypospolitej w XVI-XVII w., „Roczniki Stowarzyszenia Miłośników Jarosławia” 9 (1972-1976); H. Obuchowska-Pysiowa, Udziat Krakowa w handlu zagranicznym Rzeczypospolitej w pierwszych latach XVII w., Wrocław 1981; A. Dziubiński, Na szlakach Orientu. Handel między Polska a Imperium Osmańskim w XVI-XVIII w., Wrocław 1998. 
miasta z całej Europy i Azji: najwięcej jest Greków, Turków, Ormian, Tatarów, Wołochów, Węgrów, Niemców i Włochów. I mimo, że na skutek wojen miasto nieco podupadło, Grecy którzy są pod pilnym nadzorem miejskiego tłumacza, co roku sprzedają tu około 500 beczek małwazji”’2.

Taka aktywność Greków nie była dla Lwowa zjawiskiem zupełnie nowym, raczej przedłużeniem wcześniejszych kontaktów Bizancjum z terenami dawnego Księstwa Halicko-Włodzimierskiego ${ }^{3}$, które całkowicie przejęte zostały w spadku przez państwo polskie.

Pierwszą zachowaną pisemną wzmiankę o kupcu greckim we Lwowie spotykamy w 1382 roku $^{4}$. Ciekawe, że przybył on do miasta drogą niekoniecznie popularną u Greków, bo przez Kraków. Z upływem lat liczba kupców greckich wzrasta, skoro już w roku 1441, w związku z wprowadzeniem w życie przepisu o obowiązku korzystania we Lwowie w trakcie działań prawnych z instytucji tłumaczy ${ }^{5}$, pojawia się wśród innych języków, traktowany jako bardzo ważny, język grecki ${ }^{6}$.

W następnych latach coraz częściej spotykamy informacje o kupcach tureckich pochodzenia greckiego odwiedzających co roku jarmarki Lwowa, Przemyśla czy Jarosławia. Jednak o Grekach jako zwartej grupie, posiadających własną tożsamość etniczną, a mieszkających na stałe we Lwowie, możemy mówić dopiero od drugiej połowy XVI wieku. Co prawda już od momentu upadku Konstantynopola w 1453 roku przewidywano możliwość napływu uchodźców z terenu bałkańskiego. We Lwowie wydano nawet rozporządzenie, że wolno ich wpuszczać do miasta tylko po złożeniu specjalnej przysięgi ${ }^{7}$. Jednak, w ostatecznym rachunku, do wielkiej emigracji byłych mieszkańców Bizancjum nie doszło. Niepoślednią rolę odegrał fakt, że ustawodawstwo miasta Lwowa nie było dla tych przybyszy zbyt korzystne. Jeszcze w 1356 roku król Kazimierz III Wielki wyznaczył prawne ramy działalności różnych grup wyznaniowych, protegując przy tym szczególnie katolicką wspólnotę we Lwowie ${ }^{8}$. Wspólnoty: ruska, ormiańska i żydowska uzyskały wprawdzie prawne

${ }^{2}$ S. Rachwał, Jan Alnpek i jego opis miasta Lwowa, Lwów 1930.

${ }^{3}$ И. Лильо, Контакты греческого Востока с городами Галиикой Руси в XI-XV вв., [w:] Byzantium, new peoples, new powers: the Byzantino-Slav contact zone, from the ninth to the fifteenth century, ed. by M. Kaimakamova, M. Salamon, M. Smorąg-Różycka, Cracow 2007 (Byzantina et Slavica Cracoviensia, 5).

${ }^{4}$ Центральний Державний Історичний Архів України у Львові (ЦДІА), Ф. 52, оп. 2 , спр. 1, с. 4. Opublikowane: Pomniki dziejowe Lwowa z archiwum miasta, t. 1, Najstarsza księga miejska. 1382-1389, wyd. A. Czołowski, Lwów 1892, s. 4.

${ }^{5} 16$ czerwca 1441 roku król Władysław III pozwolił władzy miejskiej samodzielnie wybierać tłumaczy, zob. Привілеї міста Львова (XIV-XVIII cm.), wyd. М. Капраль, Львів 1998, s. 86.

${ }^{6}$ Д. Зубрицький, Хроніка міста Львова, Львів 2002, s. 92.

${ }^{7}$ Б. Зіморович, Потрійний Львів. Leopolis Triplex, Львів 2002, s. 83.

${ }^{8}$ Привілеї національних громад міста Львова (XIV-XVIII cm.), ред. М. Капраль, Львів 2000, s. 6 . 
uznanie, lecz nigdy nie osiągnęły one tego poziomu uprzywilejowania, który przyznano katolikom. Prawosławni Grecy od momentu przyjazdu do Lwowa byli zmuszeni wybierać między utratą tożsamości religijnej a przyłączeniem się do grona prawosławnych Rusinów.

Ten sojusz z Rusinami nie służył wyłącznie sprawie zachowania tożsamości. Dzięki wsparciu Rusinów Grecy łatwiej dopuszczani byli do prawa miejskiego iuxta alios cives Ruthenos ${ }^{9}$. W taki właśnie sposób w 1584 roku przyjęty został do grona mieszczan Grek Jani Affendyk ${ }^{10}$. W 1588 roku następny Grek - Emmanuel Arfani z wyspy Chios otrzymuje prawa mieszkańca Lwowa przy udziale wójta, dwóch ławników i członków wspólnoty Rusinów: Dmytra Krasowskiego i Iwana Diaka ${ }^{11}$. W podziękowaniu za łaskę, która go spotkała, kupił dla arsenału miejskiego broń ${ }^{12}$. Kilku młodzieńców greckich zdobędzie te same prawa poprzez ślub z niewiastami z greckich lub ruskich rodzin. To wszystko pozwoli Grekom na nawiązywanie niezbędnych kontaktów i na szybką integrację.

Duże znaczenie dla rozwoju diaspory greckiej we Lwowie miał przywilej Zygmunta II z 1472 roku, który zachęcał kupców wschodnich do transportowania towarów do Europy Zachodniej przez Lwów. Rada miasta była też zainteresowana szerszą obecnością tak znakomitych inwestorów. Wszystko to powodowało, że z upływem czasu Grecy coraz chętniej zostawali we Lwowie, kupowali nieruchomości, zakładali rodziny, umacniając swoją pozycję społeczną. Bartłomiej Zimorowicz w swojej kronice wspomina jako popularne miejsce zamieszkania Greków we Lwowie obecną ulicę Gliniańską na Halickim Przedmieściu ${ }^{13}$. Od drugiej połowy XVI wieku powstaje we Lwowie mała, ale zwarta i aktywna, kolonia grecka.

Problem jednak stanowi jej klasyfikacja. Wcześniej już wspominaliśmy, że dominacja Ormian w handlu wschodnim, a także włączanie się Greków do życia w miejscowej społeczności jako części wspólnoty ruskiej powodowały, że Grecy zostali usunięci w cień w historii Lwowa. W swojej rozprawie o sławnych mieszkańcach miasta prof. W. Łoziński wspomniał jedynie o znaczeniu Greków dla miasta na podstawie badania znanych rodów ${ }^{14}$. Trochę poprawiła sytuację rzetelna rozprawa F. Sribnego o miejscu Greków we wspólnocie ruskiej ${ }^{15}$.

\footnotetext{
${ }_{9}^{9}$ М. Капраль, Украӥнська громада на вулииі Руській Львова в 1550-1585 рр., „Вісник Львівського національного університету ім. І. Франка. Серія історична” 37 (2002) cz. 1, s. 152.

${ }^{10}$ ЦДІА України у м. Львові, Ф. 52, оп. 2, спр. 648, с. 113.

${ }^{11}$ Tamże, s. 158.

${ }^{12}$ Tamże, Liber electionum I., 1079 r., 150.

${ }^{13}$ Б. Зіморович, Потрійний Львів..., dz. cyt., s. 84.

${ }^{14}$ W. Łoziński, Patrycjat i mieszczaństwo lwowskie w XVI-XVII wieku, Lwów 1902.

${ }^{15}$ Ф. Срібний, Студї над організачією Львівської Ставропігї̈ від кіния ХVI до першої половини XVII cm., [w:] Записки Наукового Товариства ім. Шевченка, t. 108, s. 1-38, t. 112, s. 59-73, t. 114, s. 25-26.
} 
Niestety, wskutek różnych przyczyn, poruszony przez tych badaczy temat został na wiele lat zaniechany.

Ostatnie badania w archiwach miasta, a także wykorzystanie tak ważnego źródła, jaki stanowią dokumenty bractwa stauropigialnego, wskazują, że mimo włączania się Greków w ramach prawosławnej grupy do wspólnych działań na rzecz obrony swoich praw przed Radą Miasta Lwowa, a także wspólnego $\mathrm{z}$ tą grupą reprezentowania interesów ludności prawosławnej w Radzie miasta Grecy demonstrowali jednak okresowo swoją odrębność etniczną, a zwłaszcza dbali o samodzielność ekonomiczną. Rodziny Affendyków, Madzapetów, Mazarakich, Paparów do końca XVII wieku zachowywały swoją tożsamość narodową $\mathrm{i}$ broniły swych interesów ekonomicznych, w czym pomagało przede wszystkim dbanie o zwartość własnej grupy oraz powiązania osobiste ${ }^{16}$.

Analiza zawodowej, prawnej i społecznej aktywności Greków we Lwowie w XVI i XVII wieku pozwała na wyróżnienie następujących kategorii greckich mieszkańców tego miasta:

1) kupcy przybywający czasowo na jarmarki ${ }^{17}$;

2) kupcy mający stałe placówki handlowe lub swoich handlowych przedstawicieli we Lwowie ${ }^{18}$;

3) greccy członkowie Bractwa Stauropigialnego, których obejmowało prawo miejskie;

4) nauczyciele szkoły prawosławnej, mnisi i rzemieślnicy.

Jeżeli pierwsza, największa liczebnie kategoria tylko okresowo wspomagała żywioł grecki we Lwowie, to następne zasługują na większą uwagę i dokładniejszą analizę.

Ważne znaczenie w integracji Greków miało pochodzenie wielu z nich z tych samych miejscowości lub nawet przynależność do jednej rodziny. We Lwowie Grecy byli niekiedy dzieleni na dwie duże grupy określane mianem: Graecus de Galata i Graecus de Constantinopoli. Wśród ostatnich spotykamy nawet przedstawicieli rodów arystokratycznych ${ }^{19}$. Po zajęciu przez Turków wysp należących do Genui i otwarciu dróg handlowych w drugiej połowie XVI wieku, do Lwowa trafiła grupa Greków i Włochów z wyspy Chios. W księgach grodzkich miasta spotykamy nazwiska Graecus de insula Chios, mercator advena Leopoliensis. Około 1548 roku do Lwowa licznie napływają

\footnotetext{
${ }^{16}$ I. М. Лильо, Родина Папара у Львові, [w:] Подвижники й меиенати. Грецькі підприємиі та громадські діячі в Україні XVII-XIX ст., Київ 2001, s. 105-111.

${ }^{17}$ Największe jarmarki we Lwowie miały miejsce w święto św. Agnieszki 22 stycznia i latem na Św. Trójcy, zob. Ł. Charewiczowa, Handel średniowiecznego Lwowa, Lwów 1925, s. 23 (Studia nad Historją Kultury w Polsce, 1).

${ }^{18} \mathrm{~J}$. Motylewicz, Miasta ziemi przemyskiej i sanockiej w drugiej połowie XVII i XVIII wieku, Przemyśl-Rzeszów 1993, s. 179. Zaliczenia tej czy innej osoby do jednej z grup dokonywano na podstawie prawnej i społecznej pozycji, a także w oparciu o kryterium zawodowe.

${ }^{19}$ A. Dziubiński, Na szlakach Orientu..., dz. cyt., s. 94.
} 
Grecy z Krety. Niektórzy noszą nazwiska zmodyfikowane na wzór włoski, jak - Januli Marnis czy Naksio Insula ${ }^{20}$. Grecy z Konstantynopola i innych terenów Imperium Osmańskiego są niekiedy identyfikowani w księgach Lwowa jako np. Jani Turek albo po prostu Grek z Turcji (sic!). Czasem sami Turcy podawali się zresztą za Greków, licząc na preferencje handlowe ${ }^{21}$.

Inną, dużą grupę stanowili Grecy pochodzenia wołoskiego. Byli to mieszkańcy Jas, Suczawy, Reni lub innych miast. W większości występują oni jako pośrednicy w handlu towarami wschodnimi na terenie Polski. Jednakże odmiennie od tureckich Greków reprezentowali mniejszą siłę finansową. Z nimi też Polska miała najwięcej kłopotów, bo naczęściej przyłapywani byli na różnego rodzaju działaniach kryminalnych ${ }^{22}$. Mimo wszystko, z roku na rok liczba Greków wzrastała. Według obliczeń w XVI i na początku XVII wieku odnotowano na lwowskim rynku działalność ok. 700 kupców greckich ${ }^{23}$.

Grecy demonstrowali swoją odrębność nie tylko pod względem religii czy poprzez specyfikę swego stylu życia codzinnego. W handlu również różnili się od Ormian czy Żydów. Absolutnie dominowali w handlu winem. Prawie nie dopuszczali do obrotu tym towarem Rusinów. O tym, jak duże transakcje przeprowadzano na polskim rynku, informują dane przekazane przez konsula Wenecji w Konstantynopolu Nikola Barbariga. Według niego co roku wysyłano do Polski ok. 1000-1500 kuf wina ${ }^{24}$.

Największe zagrożenie dla handlu winem dla lwowskich Greków nastąpi dopiero od 1567 roku, kiedy Zygmunt II August wyda dla wpływowego na dworze sułtańskim Żyda J. Nassiego pozwolenie na wolny handel winem w Polsce ${ }^{25}$. Ta sprawa wywołała niepokój szczególnie we Lwowie. Dzięki zgodnym dzałaniom Grecy doprowadzili jednak spółkę Nassiego do upadku. Ciekawie, że ta sytuacja była jednym z nielicznych epizodów, w których Grecy zostali aktywnie wsparci przez kupców ormiańskich ${ }^{26}$.

Bardzo ciekawych faktów z życia Greków we Lwowie dostarczają również badania nad historią poszególnych rodów. Za najwybitniejszą postać lwowianina greckiego pochodzenia jest uważany kupiec z wyspy Krety Konstantyn Korniakt. Swoją fortunę zdobył, mieszkając w Mołdawii, a do Lwowa przeniósł się dopiero po śmierci brata Michała, po którym odziedziczył spadek. Od drugiej połowy XVI wieku zostanie najbogatszym obywatełem miasta, członkiem bractwa

${ }^{20}$ Tamże, s. 95.

${ }^{21}$ A. Treiderowa, Mieszkańcy Wschodu we Lwowie, „Miesięcznik Heraldyczny” 14 (1935) nr 10, s. 157.

${ }^{22}$ A. Dziubiński, Na szlakach Orientu..., dz. cyt., s. 94.

${ }^{23}$ В. Кривонос, До питання..., dz. суt., s. 60.

${ }^{24}$ Е. М. Подградская, Экономические связи Молдавского княжества и Балканских стран с Русским государством в XVII вв., Кишинёв 1980, s. 255.

${ }^{25}$ Akta Grodzkie i Ziemskie z czasów Rzeczypospolitej Polskiej, t. X, Lwów 1884, nr 1382, 1399.

${ }^{26}$ ЦДІА України у м. Львові, Ф. 52, оп. 2, спр. 1302, с. 300, 366, 367. 
stauropigialnego i fundatorem kilku okazałych budowli, które do dzisiaj pozostają swoistą wizytówką Lwowa. Niestety, właśnie los jego rodziny jest przykładem szybkiego tracenia przez Greków tożsamości narodowej, porzucanej na rzecz korzyści politycznych i ekonomicznych wynikających z polonizacji ${ }^{27}$. Mimo że sam Konstantyn Korniakt pozostał wierny Cerkwi Prawosławnej, już jego wnukowie będą dzelnie wspierać stronę polską w wojnie z kozakami Bogdana Chmielnickiego.

Następnym wątkiem, który pozwala ujawnić odrębność lwowskich Greków od reszty obywateli miasta, jest interesujące zjawisko podejmowania działalności szpiegowskiej przez najbardziej znanych spośród ich grona dla dobra odnowienia niepodległego państwa greckiego. Po upadku Konstantynopola Grecy mieszkający na terenach od Stambułu do Lwowa i Moskwy na różne sposoby walczyli o realizację tej idei. Wielu z nich liczyło na wykorzystanie konfliktu między Polską, Carstwem Moskiewskim i Turcją na korzyść swojego narodu. Zbyt aktywna działalność, szczególnie greckich duchownych, budziła niepokój we wspomnianych trzech państwach. Królowie polscy wiedzieli o tym, że wielu spośród wędrujących Greków para się działalnością szpiegowską. Do starostów ukraińskich wysyłano listy z poleceniem zwracania szczególnej uwagi na duchownych greckich przekraczających granice ${ }^{28}$. Grecy brali udział w każdej prawie delegacji przekraczającej polską granicę na drodze do Moskwy.

Właśnie we Lwowie łatwo można było znaleźć kadrę dla służby dyplomatycznej na Wschodzie. Po stronie Polski pracował Grek lwowski Jan Mazaraki, którego wysłano do Persji na czele poselstwa podejmującego próbę utworzenia antytureckiej koalicji ${ }^{29}$. Inni Grecy wspierali ideę nowej wojny z Turcją jako szansę dla swojej ojczyzny. Niestety, wskutek trudnej sytuacji, która zaistniała dla Polski po powstaniu Bogdana Chmielnickiego, część lwowskich Greków zmieniła swoje opcje polityczne na korzyść Moskwy. Informatorem rosyjskim był znany we Lwowie Grek Jerzy Papara. W rozmowie z rezydentem rosyjskim w Polsce Borisem Michajłowem w 1692 roku chwalił się on swą współpracą jako informator oddający usługi jeszcze dla Wielkiego Księcia Alekseja Michajłowicza. Podobne kontakty miał też jego bratanek - Kiriak Papara ${ }^{30}$. Inny Grek, członek bractwa stauropigialnego Kiriak Isarowicz, aktywnie wspomagał informacjami następnego rezydenta rosyjskiego - Wasilija Tiapkina. Agentem

${ }^{27}$ Konstanty, O Korniakcie i losach jego rodziny, [w:] І. Лильо, Нариси з історії..., dz. cyt.

${ }^{28}$ Akta grodzkie i ziemskie z czasów Rzeczypospolitej Polskiej z archiwum tak zwanego bernardyńskiego we Lwowie wskutek fundacyi śp. Alexandra hr. Stadnickiego. Wyd. staraniem Galicyjskiego Wydziału Krajowegot. 1-24, Lwów 1909-1931., tu: t. 10 nr 2691, s. 173.

${ }^{29}$ S. Uruski, Rodzina. Herbarz szlachty polskiej, t. 10, Warszawa 1916, s. 277.

${ }^{30}$ Н. Н. Бантыш-Каменский, Реестры по греческим делам Московского Архива Коллегии иностранных дел Российский государственный архив древних актов, Ф. 52, оп. 1 , Москва 2001, s. 186 (Россия и христианский Восток, вып. 2, отв. ред. Б. Л. Фонкич). 
był również Grek Piotr Affendyk ${ }^{31}$. Większość z tych Greków opuściła miasto po nieudanej dla Rosjan wyprawie cara Piotra I na Turków w 1711 roku. Jednak ich usługi zostały docenione i z czasem zostali oni przyjęci na służbę carską, osiągając wysoką pozycję społecznąą

Do ostatniej grupy, nielicznej, ale bardzo zasłużonej dla diaspory i wspólnoty prawosławnej, należą nauczyciele greccy, którzy pracowali w szkole działającej przy Cerkwi Ruskiej. Warto wyodrębnić postać najwybitniejszego z nich - biskupa Arseniusza z Elassonu. Do Lwowa trafił w 1585 roku, wracając z Moskwy jako członek delegacji wysłanej przez patriarchę Feolepta. Na prośbę miejscowych prawosławnych pozostawał we Lwowie i mieszkał tu przez dwa lata ${ }^{33}$. Dzięki jego staraniom w krótkim czasie powstaje we Lwowie gramatyka do nauczania języka greckiego ${ }^{34}$. Ta praca znana jako „Adelfotes” stanie się wzorcem dla przygotowania dalszych programów używanych w edukacyjnych ośrodkach prawosławnych w Polsce. W 1637 roku w dokumentach bractwa notowani są już inni nauczyciele: Atanaziusz Grek i Mikołaj Grek ${ }^{35}$.

Ostatnia zawodowa grupa grecka na terenie Lwowa i obszarów sąsiadujących z miastem to producenci tkanin wzorowanych na modzie orientalnej. Co najmniej od czasów króla Jana III Sobieskiego styl wschodni dominuje w stroju szlachty i mieszczaństwa polskiego. Czapraki dla koni, broń biała wschodnia lub koszule tureckie to marzenie każdego rycerza. Jednak szczególną popularność uzyskują pasy męskie, które na wiele lat pozostaną elementem ubioru szlacheckiego, szczególnie w Galicji. Zazwyczaj sprowadzano te pasy z Turcji i nawet rozróżniano kilka ich odmian. Wszakże już w drugiej połowie XVII wieku import tkanin ze Wschodu uległ zmniejszeniu. W rezultacie greccy tkacze zaczęli organizować produkcję takich tkanin na miejscu. Najważniejszym ośrodkiem między rokiem 1640 a 1650 było miasto Brody położone ok. 100 km od Lwowa. Mieszkało tam kilku greckich mistrzów ${ }^{36}$. Najbardziej znanym z nich stał się ,złotogłownik, mieszczanin i kupiec brodzki, auritextor, civis

${ }^{31}$ Ю. Э. Шустова, Посольские книги как источник по истории введения греко-католической унии на украинских землях в составе Речи Посполитой в 70-90-х годах XVII века, [w:] Источниковедение: поиски и находки. Сборник научных трудов, вып. 1, Воронеж 2000, s. 110-120.

${ }^{32}$ В. Томазов, Из генеалогии рода Мазараки, [w:] Україна - Греція: історія та сучасність: Тези II міжнародної конференції 22-24 лютого 1995, Київ 1995, s. 128-131.

33 А. Дмитриевский, Архиепископ Элассонский Арсений и мемуары его из истории русской истории по рукописи трапезунтского Сумелийского монастыря, Київ 1899, s. 203.

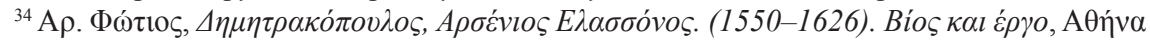
1984.

35 Ф. Срібний, Студї..., dz. cyt., t. 108, s. 16.

${ }^{36}$ T. Mańkowski, Orient $w$ polskiej kulturze artystycznej, [w:] Studia z historii sztuki, t. 8, Wrocław-Kraków 1959, s. 40. 
et negotiator Brodensis famatus" Manuel Korfiński z wyspy Korfu ${ }^{37}$. Zaprosił on do miasta innych Greków i pod opieką właściciela miasta Aleksandra Koniecpolskiego rozpoczęto masową produkcję ,pasów tureckich”. A ponieważ Koniecpolski miał we Lwowie swoją posiadłość w postaci jurydyki, w 1644 roku Korfiński także w niej założył produkcję złotogłowów i innych tkanin. Wcześniej, bo jeszcze w 1637 roku, inny Grek - Aleksander Dymowicz - „Graecus Constantinopolitanus opifex fila videlicet ductilia ex auro et argento operando et ex arte elaborando, alias ciągnione złoto i srebro" też pracował we Lwowie ${ }^{38}$. Wiemy, że obaj współpracowali ze sobą, a o działalności fabryki założonej przez Korfińskiego znajdujemy wiadomości jeszcze w 1745 roku.

Ten krótki przegląd dziejów greckiego żywiołu na gruncie lwowskim jest jedynie ilustracją niektórych interesujących epizodów z codziennego życia miasta. Nasza rozprawa nie uwzględnia wszystkich procesów związanych z diasporą grecką, ale pozwala stwierdzić, że odegrała ona ważną rolę w kształtowaniu historii i kultury Lwowa, szczególnie w XVI i XVII wieku. Mamy nadzieję, że ten kierunek badań zasługuje na kontynuację w przyszłości.

\section{Abstrakt}

Lwów będący ważnym centrum życia ekonomicznego na pograniczu polsko-ukraińskim daje doskonałą okazję do badań nad historią małych grup etnicznych mieszkających na tym terenie od czasów wczesnego średniowiecza. O Grekach jako zwartej grupie, posiadających własną tożsamość etniczną, a mieszkających na stałe we Lwowie, możemy mówić od drugiej połowy XVI wieku. Chociaż przybywali tutaj już po upadku Konstantynopola w 1453 roku, to przez długi czas jako chrześcijanie prawosławni zmuszeni byli wybierać między utratą tożsamości religijnej a przyłączeniem się do grona prawosławnych Rusinów. Zróżnicowanie Greków mieszkających we Lwowie w XVI i XVII wieku - poddanej analizie w niniejszym artykule - odzwierciedla aktywność tej grupy, wśród której wyróżnić można kupców, przyjeżdżających czasowo, kupców posiadających stałe placówki, nauczycieli, rzemieślników i innych.

\section{Słowa kluczowe}

Lwów, Grecy, tożsamość

\section{Abstract}

The Greeks in Lvov: forgotten citizens

An important center of economic life located on the Polish-Ukrainian border, Lvov offers the opportunity to conduct research into the history of small ethnic groups living in that area since the early Middle Ages. Greeks can be referred to as a tight group with their own ethnic identity, and at

${ }^{37}$ I. Созанський, 3 минувшини м. Броди. Причинки до історії міста в XVII в. (Репринтне видання 1911 р.), Броди 2003, s. 25-26.

${ }^{38}$ ЦДІА України у м. Львові, Ф. 52, оп. 2, спр. 45, с. 1512. 
the same time living permanently in Lvov, since the second half of the $16^{\text {th }}$ century. Although they arrived here after the fall of Constantinople, in 1453, being Orthodox Christians, they were forced to choose between losing their religious identity and joining a group of Orthodox Ruthenians for a long time. The diversity of the Greeks living in Lvov in the $16^{\text {th }}$ and $17^{\text {th }}$ centuries - analyzed in the article - is reflected in the activity of this group, among which we can distinguish temporal merchants, merchants with permanent shops, teachers, craftsmen and others.

\section{Keywords}

Lvov, Greeks, identity

\section{Bibliografia}

Charewiczowa Ł., Handel średniowiecznego Lwowa, Lwów 1925, s. 23 (Studia nad Historją Kultury w Polsce, 1).

Dziubiński A., Na szlakach Orientu. Handel między Polska a Imperium Osmańskim w XVIXVIII w., Wrocław 1998.

Łoziński W., Patrycjat i mieszczaństwo lwowskie w XVI-XVII wieku, Lwów 1902.

Mańkowski T., Orient w polskiej kulturze artystycznej, [w:] Studia z historii sztuki, t. 8, Wrocław-Kraków 1959.

Motylewicz J., Miasta ziemi przemyskiej i sanockiej w drugiej połowie XVII i XVIII wieku, Przemyśl-Rzeszów 1993.

Obuchowska-Pysiowa H., Udzial Krakowa w handlu zagranicznym Rzeczypospolitej w pierwszych latach XVII w., Wrocław 1981.

Pomniki dziejowe Lwowa z archiwum miasta, t. 1, Najstarsza księga miejska. 1382-1389, wyd. A. Czołowski, Lwów 1892.

Rachwał S., Jan Alnpek i jego opis miasta Lwowa, Lwów 1930.

Szczygieł R., Jarmarki jarosławskie i ich rola w handlu Rzeczypospolitej w XVI-XVII w., „Roczniki Stowarzyszenia Miłośników Jarosławia” 9 (1972-1976).

Treiderowa A., Mieszkańcy Wschodu we Lwowie, „Miesięcznik Heraldyczny” XIV (1935) nr 10.

Uruski S., Rodzina. Herbarz szlachty polskiej, t. 10, Warszawa 1916.

Wagner W., Handel dawnego Jarosławia do połowy XVII w., [w:] Prace historyczne ku uczczenia 50-lecia Akademickiego Koła Historyków Uniwersytetu J. Kazimierza we Lwowie, Lwów 1929.

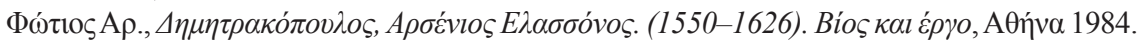

Бантыш-Каменский Н. Н., Реестры по греческим делам Московского Архива Коллегии иностранных дел Российский государственный архив древних актов, Ф. 52, оп. 1, Москва 2001, s. 186 (Россия и христианский Восток, вып. 2, отв. ред. Б. Л. Фонкич).

Дмитриевский А., Архиепископ Элассонский Арсений и мемуары его из истории русской истории по рукописи трапезунтского Сумелийского монастыря, Київ 1899.

Зіморович Б., Потрійний Львів. Leopolis Triplex, Львів 2002.

Зубрицький Д., Хроніка міста Львова, Львів 2002.

Ісаєвич Я., Братства та їх роль в розвитку української культури XVI-XVII ст., Київ 1966.

Капраль М., Украӥнська громада на вулиці Руській Львова в 1550-1585 рр., „Вісник Львівського національного університету ім. І. Франка. Серія історична”, z. 37, cz. 1, 2002.

Кривонос В., До питання про діяльність середземноморських греків у Львові в XVI - середині XVII cm., [w:] Lwów: miasto, społeczeństwo, kultura. Studia z dziejów Lwowa, t. 2, Kraków 1998, s. 59-67. 
Лильо И., Контакты греческого Востока с городами Галиикой Руси в XI-XV вв., [w:] Byzantium, new peoples, new powers: the Byzantino-Slav contact zone, from the ninth to the fifteenth century, ed. by M. Kaimakamova, M. Salamon, M. Smorąg-Różycka, Cracow 2007 (Byzantina et Slavica Cracoviensia, 5).

Лильо І. М., Родина Папара у Львові, [w:] Подвижники й меценати. Грецькі підприємиі та громадські діячі в Украӥні XVII-XIX ст., Київ 2001, s. 105-111.

Лильо І., Нариси з історії грецької громади міста Львова в 16-17 cm., Львів, 2002.

Подградская Е. М., Экономические связи Молдавского княжества и Балканских стран с Русским государством в XVII вв., Кишинёв 1980.

Привілеї міста Львова (XIV-XVIII cm.), wуd. М. Капраль, Львів 1998.

Созанський I., 3 минувшини м. Броди. Причинки до історії міста в XVII в. (Репринтне видання 1911 р.), Броди 2003.

Срібний Ф., Студії над організацією Львівської Ставропігії від кіния XVI до першої половини XVII cm., Записки Наукового Товариства ім. Шевченка (ЗНТШ), t. 108, s. $1-38$, t. 112 , s. $59-73$, t. 114 , s. 25-26.

Томазов В., Из генеалогии рода Мазараки, [w:] Украӥна - Греиія: історія та сучасність: Тези ІІ міжнародної конферениії 22-24 лютого 1995, Київ 1995, s. 128-131.

Шустова Ю. Э., Посольские книги как источник по истории введения греко-католической унии на украинских землях в составе Речи Посполитой в 70-90-х годах XVII века, [w:] Источниковедение: поиски и находки. Сборник научных трудов, вып. 1, Воронеж 2000, s. 110-120. 